\title{
Energy retrofit of historic buildings: Environmental assessment of cost-optimal solutions
}

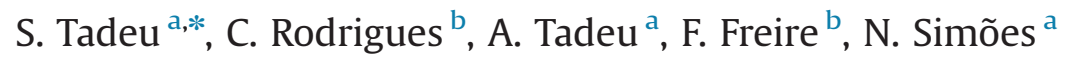 \\ a Department of Civil Engineering, FCTUC, University of Coimbra, Pólo II, Rua Sílvio Lima, 3030-790 Coimbra, Portugal \\ b ADAI - LAETA, Department of Mechanical Engineering, FCTUC, University of Coimbra, Pólo II, Rua Luís Reis Santos, 3030-788 Coimbra, Portugal
}

\section{A R T I C L E I N F O}

\section{Article history:}

Received 8 July 2015

Received in revised form

18 September 2015

Accepted 23 September 2015

\section{Keywords:}

Building retrofit

Cost optimality

Environmental impacts

Historic buildings

Life-cycle assessment (LCA)

Thermal dynamic simulation

\begin{abstract}
A B S T R A C T
This paper describes the implementation of an integrated cost optimality and environmental assessment involving alternative energy efficiency retrofit packages for a building that dates from the beginning of the 20th century. A building typical of the building stock in the centre of Coimbra (located in the central region of Portugal and recently classified as a UNESCO World Heritage Site) was used to illustrate the methodology presented. The results were also analysed for the same building in two other locations. A life-cycle (LC) model was implemented to assess different energy efficiency measures for an apartment. The economic assessment complied with European Directive 2010/31/EU. The results show that the lowest life-cycle environmental impacts were obtained for insulation thicknesses between 50 and $120 \mathrm{~mm}$, which are also cost-optimal. It is also shown that insulation thicknesses of more than $80 \mathrm{~mm}$ do not improve energy efficiency or global cost reduction. This paper shows that, even though historic buildings in Portugal do not have to comply with building energy codes, significant energy savings can be achieved for them without changing their historic character. It was also concluded that economic and environmental costs can both be minimised by choosing the most suitable energy efficiency retrofit measures.
\end{abstract}

c) 2015 Elsevier Ltd. All rights reserved.

\section{Introduction}

Buildings are an important source of environmental impacts, not only during the construction phase but also the due to the long term impact of energy use over their life span. The residential and commercial sectors in Portugal accounted for $18 \%$ and $12 \%$, respectively, of the total final energy use in 2010 [1]. Moreover, it has been claimed that the use stage is the most costly for energy use and environmental impacts over a building's life-cycle [2-4]. However, as buildings become nearly zero energy (NZEBs), the balance shifts and the embodied phase become the most costly [5]. Moreover, user behaviour is not considered in most life-cycle and cost optimality studies.

Given their long life span, it is essential that buildings meet energy performance requirements in line with the local climate when major retrofit works are planned. European Directive 2010/ 31/EU (EPBD) [6] requires all EU state-members to establish a comparative methodological framework for the calculation of cost optimality levels for the energy performance requirements of

\footnotetext{
* Corresponding author.

E-mail addresses: sergio.tadeu@itecons.uc.pt (S. Tadeu), carla.rodrigues@dem.uc.pt (C. Rodrigues), tadeu@itecons.uc.pt (A. Tadeu), fausto.freire@dem.uc.pt (F. Freire), nasimoes@itecons.uc.pt (N. Simões).

buildings. However, buildings in World Heritage sites are not obliged to comply with these requirements since doing so may affect their architectural and historic value [7]. About 25\% of the building stock in Europe was built in the middle of the 20th century. Most of those buildings have an architectural, cultural or even historic value and represent the unique character and identity of European cities; however, they are among the largest contributors to the poor energy performance of the building sector.

Various strategies can promote the fulfilment of sustainability criteria to achieve an optimum balance between return on investment, energy savings and minimisation of environmental impacts over a building's life span. In 2012, Delegated Regulation (EU) No. 244 [8] (supplementing the EPDB) laid down rules to compare energy efficiency measures using a cost optimality approach. This methodological framework is based on the primary energy performance and cost of each measure, looking at both the macroeconomic perspective (looking at the costs and benefits of energy efficiency investments for the society as a whole) or a strictly financial viewpoint (looking only at the investment itself) [9]. From the macroeconomic perspective, there are assumed to be additional costs related to greenhouse gas emissions. However, the environmental assessment aspect of our methodology is limited and does not represent a life-cycle perspective. Life-cycle assessment (LCA) addresses the potential environmental life-cycle (LC) 


\begin{tabular}{|c|c|}
\hline \multicolumn{2}{|c|}{ Nomenclature } \\
\hline \multicolumn{2}{|c|}{ List of symbols and acronyms } \\
\hline $\mathrm{AC}$ & air conditioner \\
\hline ADENE & Portuguese national agency for energy \\
\hline CED & cumulative energy demand \\
\hline $\mathrm{CO}_{2}$ & carbon dioxide \\
\hline DHW & domestic hot water \\
\hline $\mathrm{EH}$ & electric heater \\
\hline EPBD & energy performance of buildings directiv \\
\hline EPS & expanded polystyrene \\
\hline ERSE & Portuguese energy regulator \\
\hline
\end{tabular}

FIN

GB

GHG greenhouse gas emissions

HDD heating degree days

LC life-cycle

LCA life-cycle assessment

LCI life-cycle inventory

LCIA life-cycle impact assessment

MAC macroeconomic perspective

NRPE non-renewable primary energy

$\mathrm{RPH} \quad$ air changes per hour impacts of products and systems (ISO 14040:2006) [10]. It can identify the critical components of the environmental performance of existing buildings and evaluate the potential benefit of different energy efficiency retrofit packages (set of measures applied to the building).

LCA methodology has been applied to assess the environmental impacts of building retrofit actions [11-16]. This approach has also been applied to redesign the concept of NZEB with the aim of reaching an electricity target of net zero energy assuming that these type of buildings can heavily be influenced by the energy carrier weighting factors chosen [17]. Moreover, extended inputoutput models have also been applied in environmental assessment of buildings retrofit $[18,19]$. For instance, Cellura et al. [19] developed an energy and environmental extended input output model, combined with life cycle assessment, to analyse the role of the building sector in the reduction of Italian energy consumption and $\mathrm{CO}_{2}$ emissions.

The environmental and economic assessments have mainly been applied to products/services (e.g. energy systems, materials, etc. [20-22]) and recently also to buildings. Several studies have carried out an economic assessment of energy efficiency retrofit measures, but very few include an environmental assessment of existing buildings and none do so for historic buildings. Lollini et al. [23] studied the optimisation of opaque components regarding their energy, environmental and economic impacts. Anastaselos et al. [24] created a tool to perform an integrated energy, economic and environmental evaluation of thermal insulation solutions. Kim et al. [25] assessed the carbon emissions and related costs of apartment buildings, and Kneifel [26] assessed energy efficiency measures in new commercial buildings. In the Portuguese context, Silvestre et al. [27] performed an environmental, energy and economic assessment of building assemblies for new residential buildings.

Thermal dynamic simulation has been included in LCA studies to assess the potential contribution of the occupants' preferences not only to the operational energy use of buildings, but also to trade-offs between embodied and operational energy [28]. The occupancy level of a building influences the operational energy use and the contribution of the different LC stages to the overall life span of a building [28,29]. De Meester et al. [30] and Azar and Menassa [31] emphasised the need to properly take occupancy into account at the design stage, to arrive at more reliable building energy performance estimates.

This article implements an integrated cost optimality and environmental assessment by combining alternative energy retrofit packages that can also be used in historic buildings. A building that represents the building stock in the old part of Coimbra (a city in the central region of Portugal and recently classified as a UNESCO World Heritage Site) was assessed. The same building is analysed as if it was in two other places (in the north and south of Portugal) in order to encompass different climate conditions. These two places represent the mildest (south) and coldest (north) winters in Portugal.

Even though historic buildings do not have to comply with minimum energy performance requirements, we intend to show the importance of the energy retrofitting of old constructions by looking at the potential energy savings and environmental impact reduction in cost-effective terms, without affecting their historical and architectural value. This article sets out to identify cost-optimal solutions based on an occupancy pattern and to assess whether these solutions also ensure low LC environmental impacts. Thermal dynamic simulation results were compared to seasonal steady-state method based on the Portuguese regulation on the thermal performance of buildings [32]. This comparison allows a coefficient of reduction to be applied to the seasonal method results for a specific occupancy pattern (in the thermal dynamic simulation calculations). A sensitivity analysis was also performed on the insulation cost, energy price trends and discount rate (for the financial perspective), to assess the influence on heating energy needs.

Section 2 describes the methodology. The building's characteristics, the retrofit packages, and the economic and environmental inventories are described in Section 3. Section 4 presents the cost and environmental results, as well as the sensitivity analyses. Finally, Section 5 sets out the conclusions.

\section{Methodology}

The methodology includes the selection of the main energy efficiency retrofit packages. The energy retrofit packages combine thermal insulation options for the roof (7), exterior walls (7) and floor (7), solutions for windows (including an option of reinforcement with second window frames) (2) and the use of alternative heating (3) and domestic hot water (DHW) systems (2). The parametric assessment resulted in 4116 energy retrofit packages calculated for each location (12,348 in total). Each package was calculated for three different locations, HDD (Heating Degree Days) 987, 1304 and 1924. In conjunction with the average $U$-value, HDD provides a simple metric for roughly quantifying the amount of energy required to heat this historic building over a year, in these three locations.

A life-cycle model was developed to assess nine packages selected for each location (within the cost-optimal range) and alternative insulation materials, aiming to identify optimum thickness levels in terms of non-renewable primary energy (NRPE) and greenhouse gas emissions (GHG). A life span of 30 years was assumed. Subsections 2.1-2.3 describe the methodology for energy, cost optimality and environmental impact assessments. 


\subsection{Energy assessment}

The energy needs for the use stage (operational energy) were calculated for the three locations using both the seasonal and dynamic methods, assuming the hygrothermal behaviour of the existing building (without energy efficiency retrofit measures). The seasonal steady-state method used to calculate the energy requirements was transposed from the European standards $[33,34]$ into national law [32]. EnergyPlus software was used for the thermal dynamic simulation; it is a state-of-the-art opensource tool developed by the U.S. Department of Energy [35]. A detailed energy performance simulation was performed by modelling the geometry, construction systems, internal loads, weather parameters, heating and DHW systems.

Since most Portuguese residential buildings do not have a permanent occupancy, the thermal dynamic model assumed the average occupancy pattern for Portuguese residential buildings. This occupancy pattern consists in a four-person family with a low occupancy level with loads mainly at night on weekdays and all day on weekends. It can be described as active couple who works outside the house during the day while their two children go to school. The heating system was only partially activated during occupied hours. Coefficients of reduction were calculated for each location, to be applied to the seasonal steady-state method to account for user behaviour, together with other internal heat gains that can be modelled more accurately in a dynamic approach. The dynamic model accounts for internal heat gains associated with the number of persons estimated to be in each thermal zone (occupancy density) and their metabolic activity, and the schedules defined for lighting and appliances. A steady-state analysis usually assumes default values per area for internal heat gains $\left(4 \mathrm{~W} / \mathrm{m}^{2}\right)[32]$.

\subsection{Cost optimality assessment}

Relevant economic and technical data was gathered and analysed for the cost assessment. Since the heating and DHW systems costs varied very little, the research focused on how the insulation cost variability influenced the cost-optimal retrofit packages. The cost assessment (heating and DHW systems, thermal insulation and windows) followed the EN 15459 standard and compared the different heating and domestic hot water systems, in $€ / \mathrm{kWh}$, and building envelope retrofit measures (thermal insulation and windows), in $€ / R$ ( $R$-thermal resistance unit). A tool was developed to assess the cost optimality of energy efficiency retrofit measures in buildings according to the methodology defined by the Commission Delegated Regulation (EU) No. 244 [8]. This tool performs a parametric assessment of different energy efficiency measures by calculating optimum levels of profitability from both a macroeconomic (including benefits for society) and a financial (only looking at the return on investment) perspective. All costs (materials, systems, operation and maintenance) were obtained from a market search using price sampling to assess the viability of current market costs [36].

\subsection{Environmental assessment}

An integrated life-cycle approach combining LCA and thermal dynamic simulation was implemented to assess the energy and environmental performance of selected energy efficiency retrofit measures. LCA addresses the potential environmental life-cycle (LC) impacts and consists of four interrelated steps: definition of goal and scope, life-cycle inventory (LCI), life-cycle impact assessment (LCIA) and interpretation (ISO 14040:2006) [10]. Two impact categories were assessed: non-renewable primary energy (NRPE), calculated using the cumulative energy demand (CED) method to address energy resource depletion, and greenhouse gas emissions (GHG), calculated using the IPCC assessment method [37]. The $\mathrm{CO}_{2}$ emissions factor used for electricity was $360 \mathrm{~g}$ $\mathrm{CO}_{2} \mathrm{eq} / \mathrm{kWh}$ and $202 \mathrm{~g} \mathrm{CO} \mathrm{eq} / \mathrm{kWh}$ for natural gas, according to Portuguese regulations (Order (extract) 15793-D/2013 in Portuguese). The final and primary energy conversion factors used were $2.5 \mathrm{kWh}_{\mathrm{ep}} / \mathrm{kWh}$ for electricity and $1 \mathrm{kWh}_{\mathrm{ep}} / \mathrm{kWh}$ for solid, liquid and gaseous fuels [32].

\section{Historic building: model and inventory}

The historic building is in the centre of Coimbra, in Rua Fernandes Tomas, 58-66, in the parish of Almedina (also known as the former "Rua das Fangas", the name given in the sixteenth century and related to trade in cereals). It has five floors (subbasement, basement and ground floor for commercial use, and the first and second floors for residential use, divided into four independent apartments). This building, also known as Casa das Talhas (which means house of the large clay pots), is located in a recently classified UNESCO World Heritage site. These sites impose several constraints on the building stock, such as volume, façade height, materials and design, etc. in order to preserve their historic and cultural value. The main features of the building are singleglazed wooden windows, non-insulated stone walls $(60 \mathrm{~cm}$ thick, on average) and a traditional wood frame roof with ceramic roof tiles. Fig. 1 shows a picture of the main façade of Casa das Talhas and its surroundings.

This article focuses on one apartment (with $119 \mathrm{~m}^{2}$ of living area) characteristic of dwellings in historic city centres in Europe. Fig. 2 presents the technical drawings (main façade, sections and plans) of the apartment. Table 1 presents the building dimensions, where $\mathrm{A}$ is the living area in square metres, $h$ the floor height in metres and $f, e, w$ and $r$ are the floor, walls, windows and roof, respectively.

The 4116 energy retrofit packages combined thermal insulation of the roof, exterior walls and floor, window replacement and two different heating and DHW systems. Table 2 gives details of the opaque building envelope assemblies (roof, walls, floor and windows) characterized by their thermal parameters, such as heat

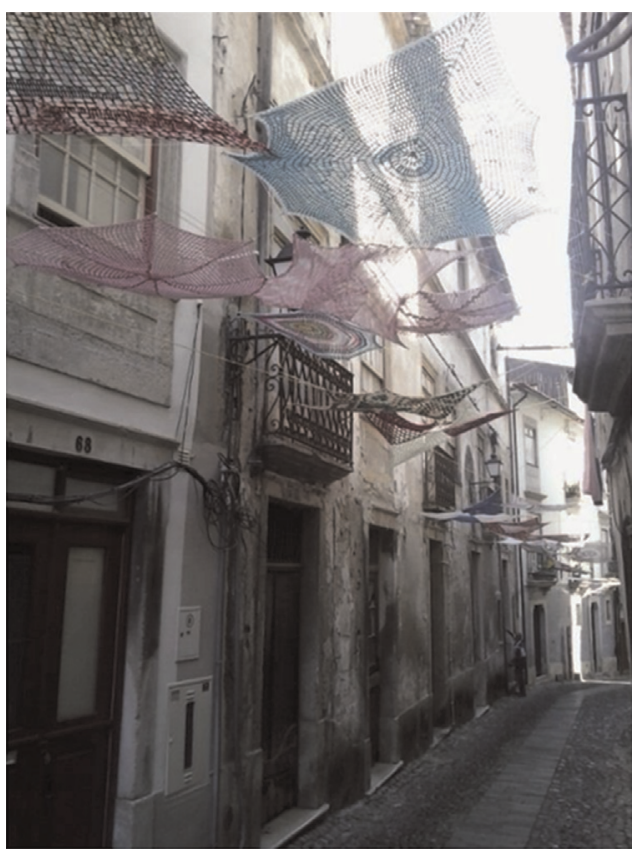

Fig. 1. "Casa das Talhas" ("House of cereals clay pots"). 
a

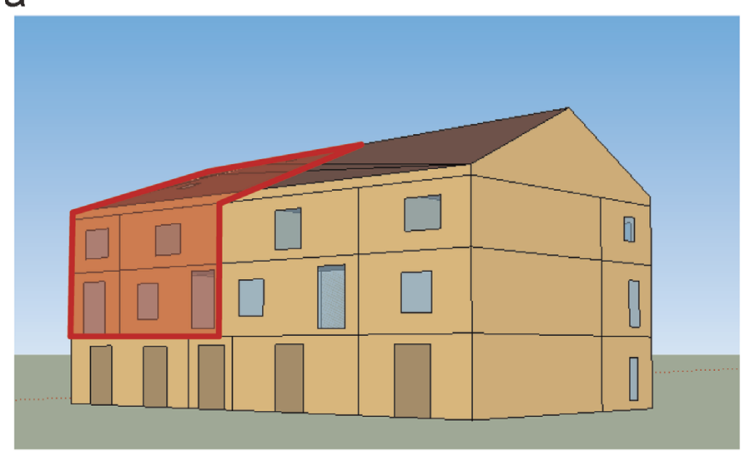

b

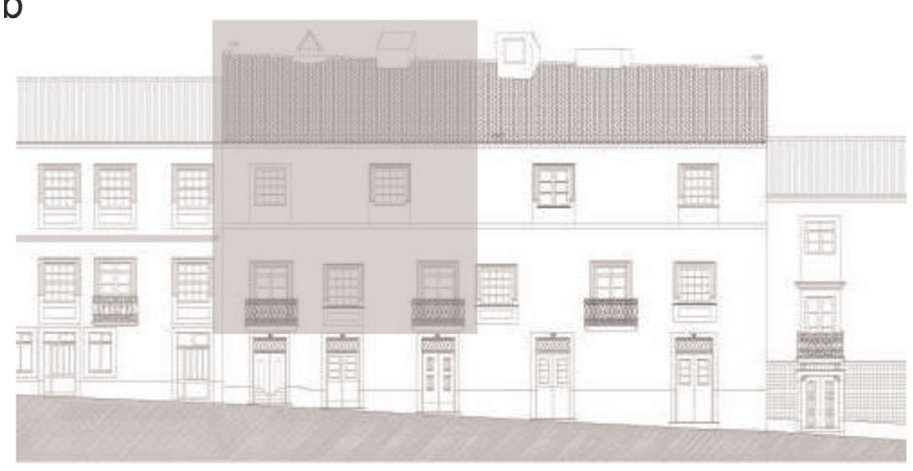

Main façade
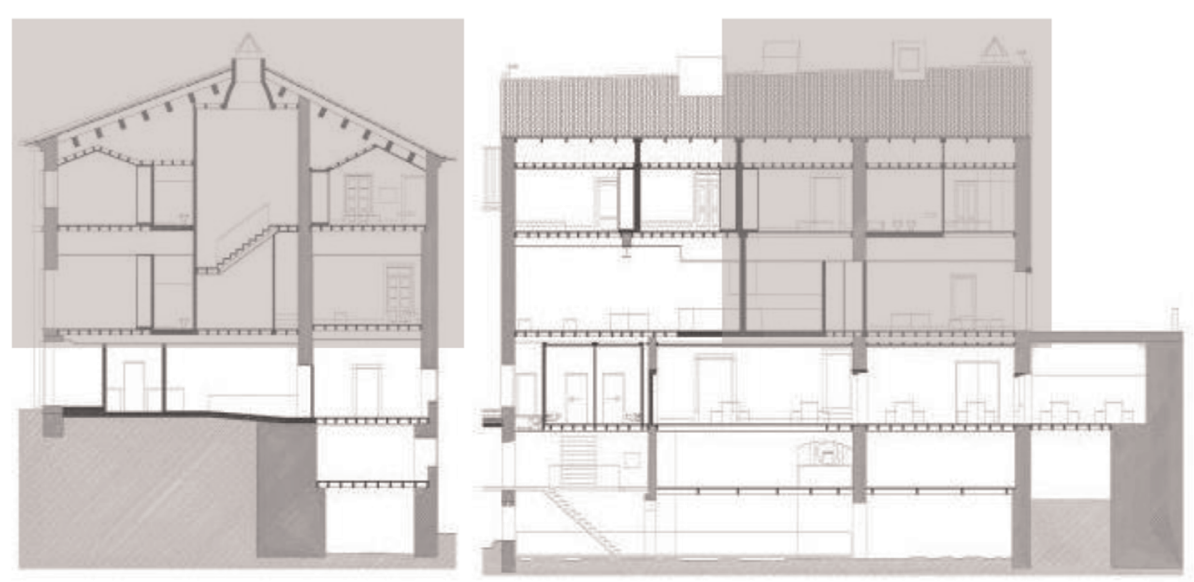

Sections A and B
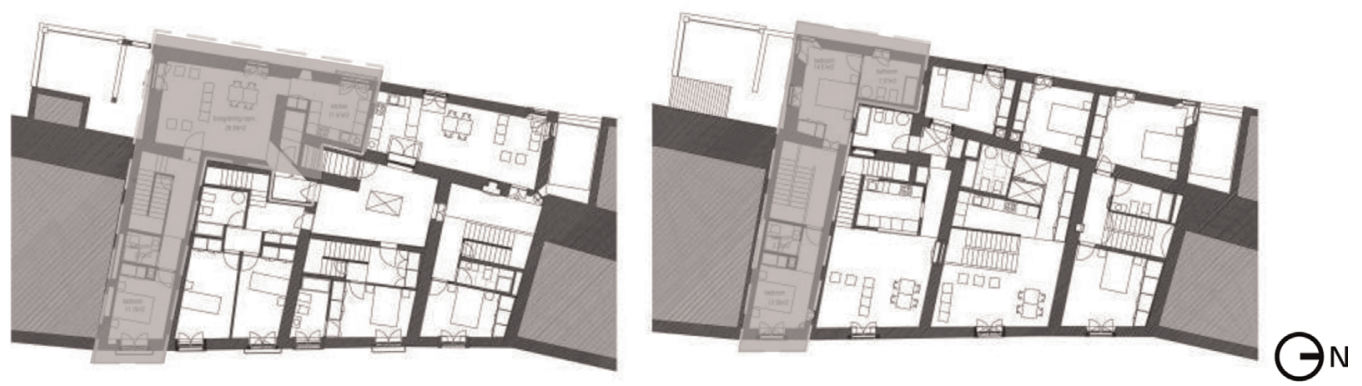

First and Second Floors

Fig. 2. Apartment: (a) 3D simplified model; (b) Main façade, sections A and B, first floor, second floor and roof plans (the apartment studied is identified with a transparency). 
Table 1

Dimensions of $\left[\mathrm{m}^{2}\right]$ and air changes per hour $\left[\mathrm{h}^{-1}\right]$ in the apartment

\begin{tabular}{ll}
\hline$A_{\mathrm{f}}$ & $70 \mathrm{~m}^{2}$ \\
$h$ & $2.85 \mathrm{~m}$ \\
$A_{\mathrm{e}}$ & $70.5 \mathrm{~m}^{2}$ \\
$A_{\mathrm{w}}$ & $17.15 \mathrm{~m}^{2}$ \\
$A_{\mathrm{r}}$ & $57 \mathrm{~m}^{2}$ \\
$\mathrm{rph}$ & $0.4 \mathrm{~h}^{-1}$ \\
\hline
\end{tabular}

Table 2

Opaque envelope assemblies (roof, walls, floor and windows) characterisationthickness in $[\mathrm{mm}]$ and heat transfer coefficient $U$ in $\left[\mathrm{W} /\left(\mathrm{m}^{2}{ }^{\circ} \mathrm{C}\right)\right]$.

\begin{tabular}{|c|c|c|c|c|c|c|c|}
\hline \multirow{2}{*}{$\begin{array}{l}\text { Roof } \\
\text { Thickness }\end{array}$} & \multirow[b]{2}{*}{$U_{\mathrm{r}}$} & \multirow{2}{*}{$\begin{array}{l}\text { Walls } \\
\text { Thickness }\end{array}$} & \multirow[b]{2}{*}{$U_{\mathrm{e}}$} & \multicolumn{2}{|l|}{ Floor } & \multicolumn{2}{|c|}{ Windows } \\
\hline & & & & Thickness & $U_{\mathrm{f}}$ & $g_{w}$ & $U_{\mathrm{w}}$ \\
\hline 0 & 2.10 & 0 & 1.84 & 0 & 1.40 & 0.85 & 5.10 \\
\hline 40 & 0.63 & 40 & 0.60 & 40 & 0.55 & 0.66 & 1.53 \\
\hline 60 & 0.47 & 60 & 0.45 & 60 & 0.42 & & \\
\hline 80 & 0.37 & 80 & 0.36 & 80 & 0.34 & & \\
\hline 100 & 0.31 & 100 & 0.30 & 100 & 0.29 & & \\
\hline 120 & 0.26 & 120 & 0.26 & 120 & 0.25 & & \\
\hline 140 & 0.23 & 140 & 0.23 & 140 & 0.22 & & \\
\hline
\end{tabular}

transfer coefficient $U$ and solar heat gain coefficient $g_{\mathrm{w}}$. The insulation thicknesses were selected based on previous studies [16], [38]. The thermal insulation material selected for this study was expanded polystyrene (EPS, with thermal conductivity of 0.036 $\left.\left[\mathrm{W} /\left(\mathrm{m}^{\circ} \mathrm{C}\right)\right]\right)$.

A life-cycle model was developed for the apartment including the following main processes: removal of the original components, construction and use stage (heating, DHW and maintenance). The end-of-life stage of the new components was not considered (dismantling scenarios and waste treatment after service life) because this cannot be accurately predicted due to the long life of buildings and is considered of minor importance for the residential sector accounting for less than $5 \%$ of total LC impacts $[39,40]$. However, this assessment included a demolition stage which represents the end-of-life of some components that will be replaced. Moreover, the end-of life may also depend on the maintenance strategy defined.The functional unit selected for this study was one square metre of living area over a period of 30 years. Inventory data for the alternative packages regarding material production and transportation was obtained from Kellenberger; Spielmann; and Althaus [41-43] and Spielmann et al. and Hischier et al. [44]. The model and life-cycle inventory were implemented using SimaPro 8 software [45].

A thermal dynamic model was implemented to calculate the energy needs of the whole building in the three locations. Each apartment and commercial area was modelled as a thermal zone with different thermal behaviour and a specific occupation pattern (internal heat gains and occupancy schedules). As this research focused on a single apartment, the operational energy considered was the heating needs of that apartment.

The Portuguese climate is classified as maritime temperate climate with Mediterranean influence under the Köppen-Geiger classification system (Csa/Csb; C: hot temperate climate; s:dry summer; a,b: hot,mild summer) [46]. The heating season begins in November and ends in mid-May (6.3 months, representing 1304 [ ${ }^{\circ} \mathrm{C}$.day] (heating degree days - HDD)). The heating and cooling setpoints were fixed at $18{ }^{\circ} \mathrm{C}$ and $25^{\circ} \mathrm{C}$, respectively, and a natural ventilation rate of 0.4 air changes per hour was considered, in keeping with the Portuguese building thermal regulation [32]. The cooling needs were not considered since the overheating period of this house is very short (heat gain coefficient is higher than the
Table 3

Heating and DHW system combinations.

\begin{tabular}{|c|c|c|c|c|c|c|}
\hline & \multicolumn{3}{|l|}{ Heating system } & \multicolumn{3}{|l|}{ DHW system } \\
\hline & Equipment & Fuel & Efficiency & Equipment & Fuel & Efficiency \\
\hline 1) & Electric heater & Electricity & 1.00 & $\begin{array}{l}\text { Gas water } \\
\text { heater }\end{array}$ & Gas & 0.60 \\
\hline 2) & Air conditioner & Electricity & 4.30 & $\begin{array}{l}\text { Gas water } \\
\text { heater }\end{array}$ & Gas & 0.78 \\
\hline 3) & Gas boiler & Gas & 0.93 & Gas boiler & Gas & 0.83 \\
\hline
\end{tabular}

reference value [32]). A total volume of 1601 per day (40 1 per person) was assumed for DHW, based on [32].

The heating and DHW systems defined as energy efficiency retrofit measures are an air conditioner (AC) (for heating only) and a gas boiler (GB) for both heating and DHW. The building is historical and would not hold panels to capture solar energy since the roof is visible from the street. Boiler biomass cannot be used due to lack of space for proper installation and heat pumps require infrastructure that would affect the building façade. Thus, the analysis does not include renewable energy technologies. Table 3 shows the possible combinations of heating and DHW systems. A set combining an air conditioner for heating and a gas water heater for DHW was compared with a gas boiler for both heating and DHW needs. The heating and DHW systems defined for the building have a coefficient of performance of 1.0 (electric heater, $\mathrm{EH}$ ) and 0.6 (gas water heater), respectively.

A four-person family (representative of a Portuguese household) was considered, with loads mainly at night (16 h) on weekdays and all day at weekends. The heating system was only partially activated during hours of occupancy. The heating schedule defined for this apartment was from 6 to $8 \mathrm{am}$ ( $9 \mathrm{am}$ at weekends) and from $6 \mathrm{pm}$ (5 pm at weekends) to $12 \mathrm{pm}$ within the defined setpoint. The maintenance tasks include conservation of the interior and exterior finishes of the building throughout the 30-year life span.

The occupancy profile used in the thermal dynamic model showed that heating needs were 32-46\% lower (depending on the location) than the needs estimated by the seasonal steady-state method. Thus, a multiplicative factor of 0.54 (HDD 987), 0.66 (HDD 1304) and 0.68 (HDD 1924) was applied to each of the 4116 packages to address the impact of the occupancy profile on the steady-state method estimates.

A cost optimality assessment was performed on 4116 energy retrofit packages for each location to identify the packages within the cost-optimal range. The most popular retrofit solutions in the Portuguese market were selected for the insulation, heating and DHW systems. The current market prices were obtained from [36] and manufacturers' associations to estimate the initial investment and maintenance costs (after retrofit). The insulation costs on the lower bound of prices include $€ 2.3$ per thermal resistance unit (€64 per $\mathrm{m}^{3}$ ) and $€ 17$ per square metre for the installation costs (labour and other materials). For the upper bound of prices, we assumed $€ 15.50$ per thermal resistance unit ( $€ 360$ per $\mathrm{m}^{3}$ ) and $€ 13.30$ per square metre for installation. Higher installation costs (€34 per square metre) were assumed for the floor insulation, for both lower and upper bounds. These bounds represent the cost range in the Portuguese market. The total initial investment cost for the defined equipment was: €984 for an electric heater; €4434 for an air-conditioner; $€ 2157$ for a gas boiler (for heating and DHW); $€ 440$ for a gas water heater. Although ISO 15459 [13] gives different percentages for maintenance costs, we assumed a $1 \%$ index on the initial investment. Costs related to building elements which do not have an influence on the energy performance of the building were omitted from the calculation, for example, floor 

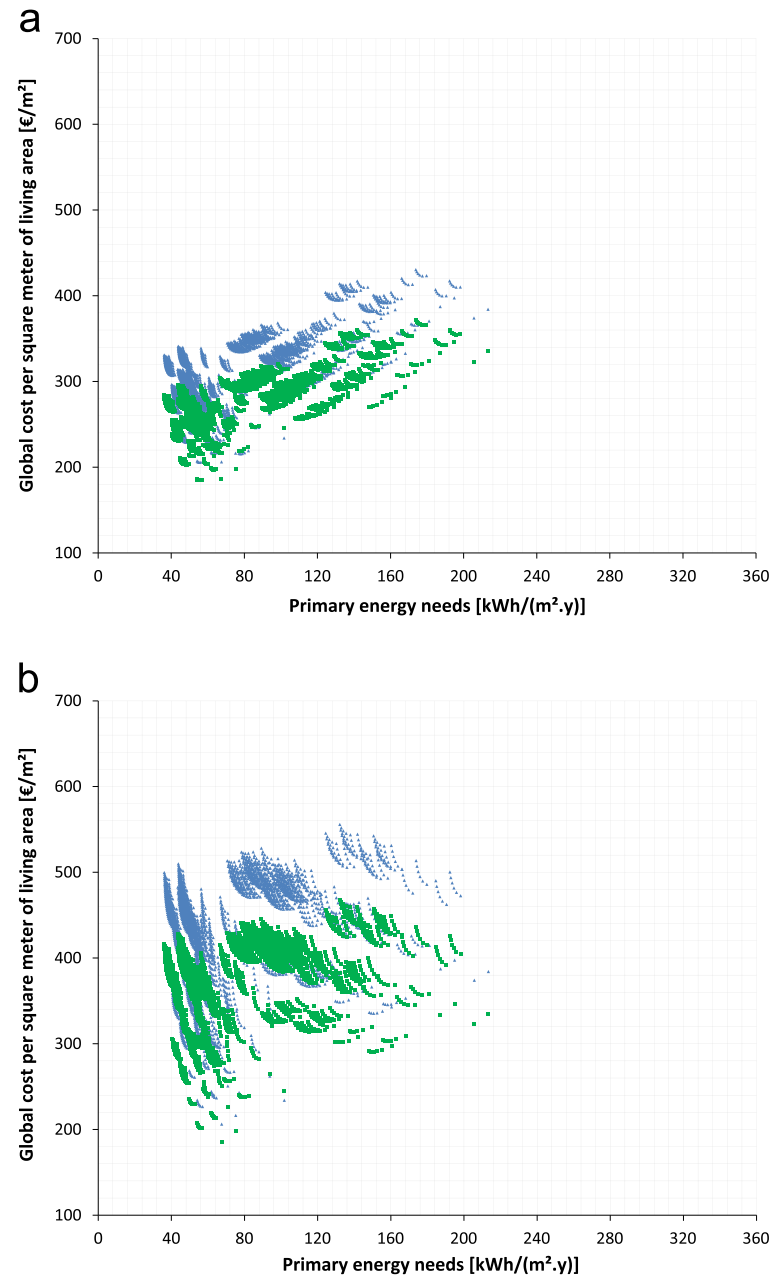

Fig. 3. Global cost $\left[€ / \mathrm{m}^{2}\right]$ and primary energy $\left[\mathrm{kWh} /\left(\mathrm{m}^{2}\right.\right.$ year $\left.)\right]$ results for 4116 retrofit packages, HDD 1304 (Coimbra), considering (a) lower bound of insulation costs and (b) upper bound of insulation costs, over a period of 30 years, in both financial (FIN) and macroeconomic (MAC) perspectives.

covering, wall painting or scaffolding costs.

The energy price trends are estimated by the EU up to 2050 [47]. The average energy cost of electricity (€0.2390) and natural gas ( $€ 0.1032)$ was obtained from the Portuguese energy regulator (ERSE) [48] and from current market prices analysis. A 6\% discount rate was considered for the financial perspective. This is the rate used in Portugal for mortgages or retrofit projects [49], according to current market figures [50].

Nine energy retrofit packages were selected for each location (from 4116) within the cost-optimal range (as shown highlighted in Fig. 4), defined in a preliminary economic assessment, for detailed assessment regarding their environmental impacts. These packages combine roof and exterior wall insulation as a result of minimising both primary energy and global costs (Pareto optimum curve).

\section{Results}

\subsection{Cost optimality assessment}

The cost-optimal curve behaviour was analysed according to both the lower and upper bounds of the insulation cost. The primary energy results for the cost optimality assessment were calculated using the seasonal steady-state method with a reduction factor (occupancy pattern). The results show that cost-optimal
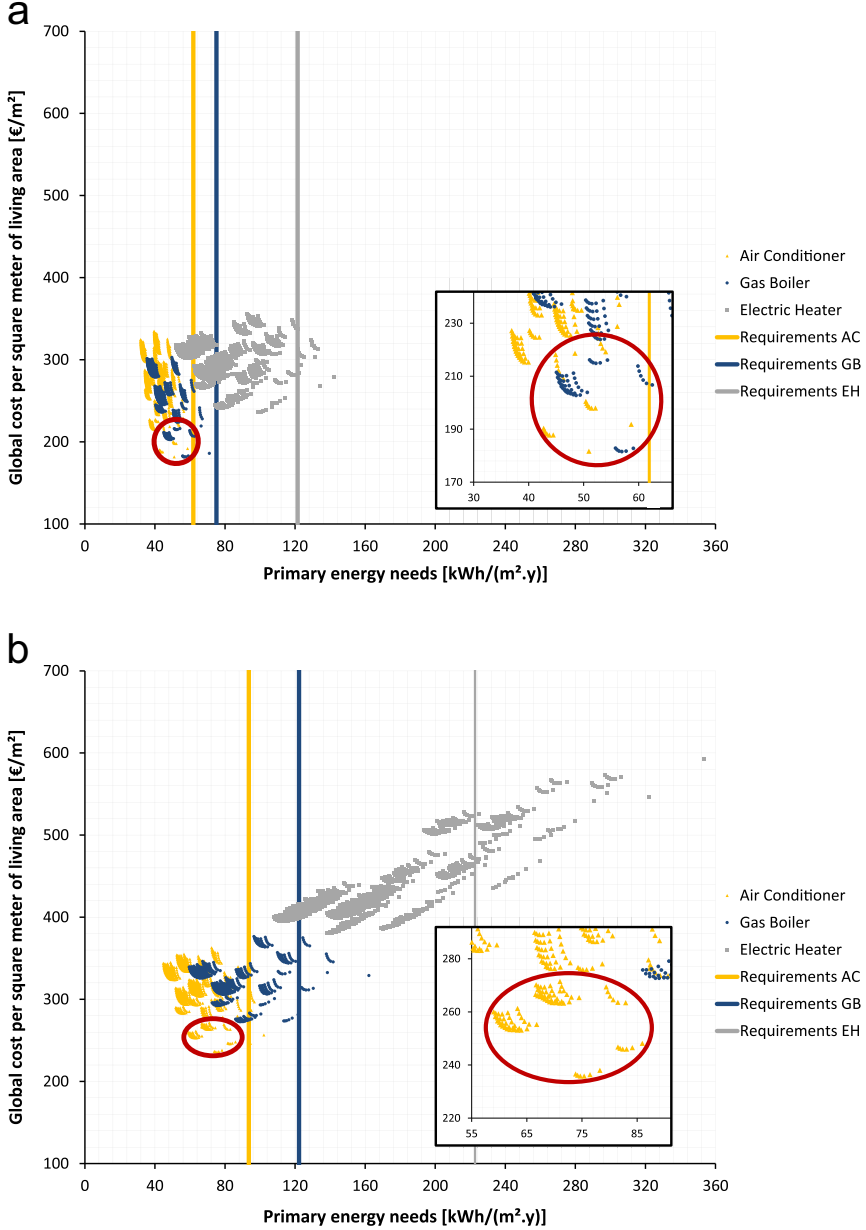

Fig. 4. Global cost $\left[€ / \mathrm{m}^{2}\right]$ and primary energy $\left[\mathrm{kWh} /\left(\mathrm{m}^{2}\right.\right.$ year $\left.)\right]$ results for 4116 retrofit packages on the lower bound of insulation costs, for (a) HDD 987 and (b) HDD 1924, over a period of 30 years.

curves change for each heating system. It can be seen in Fig. 3 that, for the same insulation thickness (just draw a vertical line to see this), the upper bound costs led to steeper curves than the lower bound, thus discouraging the investment in larger thicknesses. The cost-optimal levels in the financial and macroeconomic perspectives ( $\mathrm{FIN}=6 \%, \mathrm{MAC}=3 \%$ ) have substantial differences. The energy costs, which are significantly higher in the financial perspective due to taxes, can somehow promote investment in retrofit in a private perspective.

In the lower bound of insulation costs, the cost-optimal range varied from 53 to $67 \mathrm{kWh} /\left(\mathrm{m}^{2} \mathrm{y}\right)$ of primary energy needs for HDD 1304 (Coimbra). However, the cost-optimal insulation thickness depends on the building envelope components, roof or exterior wall, and on the location of the building. Fig. 4 shows that the costoptimal levels ranged from 43 to $63 \mathrm{kWh} /\left(\mathrm{m}^{2} \mathrm{y}\right)$ approximately, for HDD 987. For HDD 1924, the best cost-optimal level varied from 59 to $86 \mathrm{kWh} /\left(\mathrm{m}^{2} \mathrm{y}\right)$. Regarding global cost, the cost-optimal range varied from 181 to $224 € / \mathrm{m}^{2}$ for HDD 987, 205 to $235 € / \mathrm{m}^{2}$ for HDD 1304 and 236 to $270 € / \mathrm{m}^{2}$ for HDD 1924.

\subsection{Environmental assessment}

Nine energy retrofit packages per location were selected from the preliminary cost optimality assessment. It was concluded that thicknesses greater than $80 \mathrm{~mm}$ were not economically viable due to very low marginal energy savings. The cost-optimal range for Coimbra showed that the air conditioner plus gas water heater 
Table 4

Useful energy needs $\left[\mathrm{kWh} /\left(\mathrm{m}^{2}\right.\right.$ year $\left.)\right]$ for heating the apartment, by location and exterior wall and roof insulation thickness [mm].

\begin{tabular}{|c|c|c|c|c|c|c|c|c|c|}
\hline \multirow{2}{*}{$\begin{array}{l}\text { Location } \\
\text { Roof insulation thickness }\end{array}$} & \multicolumn{9}{|c|}{ HDD 987 (Southern Portugal) } \\
\hline & 0 & 0 & 0 & 40 & 40 & 60 & 80 & 100 & 100 \\
\hline Exterior walls insulation thickness & 0 & 40 & 60 & 40 & 80 & 0 & 0 & 0 & 40 \\
\hline Heating energy needs & 43.56 & 35.59 & 34.62 & 23.69 & 23.13 & 31.17 & 30.45 & 29.98 & 22.28 \\
\hline Location & \multicolumn{9}{|c|}{ HDD 1304 (Coimbra, Central Portugal) } \\
\hline Roof insulation thickness & 0 & 0 & 0 & 40 & 80 & 100 & 40 & 40 & 140 \\
\hline Exterior walls insulation thickness & 0 & 40 & 80 & 0 & 0 & 0 & 40 & 80 & 40 \\
\hline Heating energy needs & 71.99 & 59.09 & 56.57 & 53.90 & 50.75 & 49.98 & 41.28 & 38.84 & 36.54 \\
\hline Location & \multicolumn{9}{|c|}{ HDD 1924 (Northern Portugal) } \\
\hline Roof insulation thickness & 0 & 0 & 0 & 40 & 40 & 40 & 40 & 60 & 80 \\
\hline Exterior walls insulation thickness & 40 & 80 & 120 & 40 & 80 & 100 & 120 & 0 & 0 \\
\hline Heating energy needs & 98.55 & 94.65 & 92.99 & 70.82 & 66.98 & 66.03 & 65.35 & 87.42 & 85.61 \\
\hline
\end{tabular}

was the most cost-effective option ( $€ 0.055$ per kWh for heating and $€ 0.077$ per $\mathrm{kWh}$ for DHW). Different insulation thicknesses from the cost-optimal range were assessed. The floor insulation was not in the cost optimal range since it was defined as a noncost-effective measure in other studies that used market prices in Portugal [16], [38]. The high installation cost of this solution is one reason for its low economic performance. So, this measure was not included in the environmental assessment. The reinforcement with second window frames also was not in the cost optimal range since the original windows were retained in all the analysed packages. Table 4 shows the heating energy needs calculated for the three locations.

Fig. 5 shows that the exterior walls' optimum insulation level (LC tipping point) ranges from 40 (HDD 987) to $140 \mathrm{~mm}$ (HDD 1924) and the roof's optimum insulation level ranges from 40 (HDD 987) to 120 (HDD 1304). Additionally, embodied impacts account for 40\% (HDD 1924) to 80\% (HDD 987) while operational energy impact accounts for 20\% (HDD 987) to 60\% (HDD 1924). Nonetheless, embodied impacts offset the operational energy impacts in all retrofit packages in HDD 987, while in HDD 1304 this only occurs in those with exterior wall insulation. For HDD 1924, the operational energy impacts always offset the embodied impacts. Transportation accounts for about 7\% (HDD 1304) to $12 \%$ (HDD 987) of the embodied impacts. An order 2 polynomial trendline was used for total LC impacts (correlation of about 98\%) in all locations to assess the life-cycle tipping points of selected retrofit strategies (either fixing the roof insulation level and varying the exterior walls insulation level, or vice-versa).

The results by HDD are presented as follows. HDD 987 results show that the optimal insulation thicknesses (life-cycle tipping point) range from zero to $40 \mathrm{~mm}$ (exterior roof) and from 40 to $80 \mathrm{~mm}$ (exterior walls). HDD 987 embodied impacts accounts for about $60-70 \%$ of total LC impacts (varying between categories). Moreover, embodied GHG emissions offset the operational energy impacts in all retrofit strategies. The environmental benefits (reduction in total LC impacts) are very low (reduction of about $3 \%$ ) for thicknesses higher than $60 \mathrm{~mm}$ (for both roof and exterior walls). HDD 1304 results show that the optimal insulation thicknesses (life-cycle tipping point) range from 100 to $120 \mathrm{~mm}$ (exterior roof) and from 40 to $80 \mathrm{~mm}$ (exterior walls). HDD 1304 embodied impacts account for about $30-50 \%$ of total LC impacts (varying between categories). Moreover, embodied GHG emissions offset the operational energy impacts in all insulated retrofit strategies with exterior walls insulation. The environmental benefits (reduction in total LC impacts) are very low (reduction of about 5\%) for thicknesses higher than $80 \mathrm{~mm}$ (for both roof and exterior walls). HDD 1924 results show that the optimal insulation thicknesses (life-cycle tipping point) range from 80 to $100 \mathrm{~mm}$ (exterior roof) and from 100 to $140 \mathrm{~mm}$ (exterior walls). HDD 1924 embodied impacts account for about $35-60 \%$ of total LC impacts
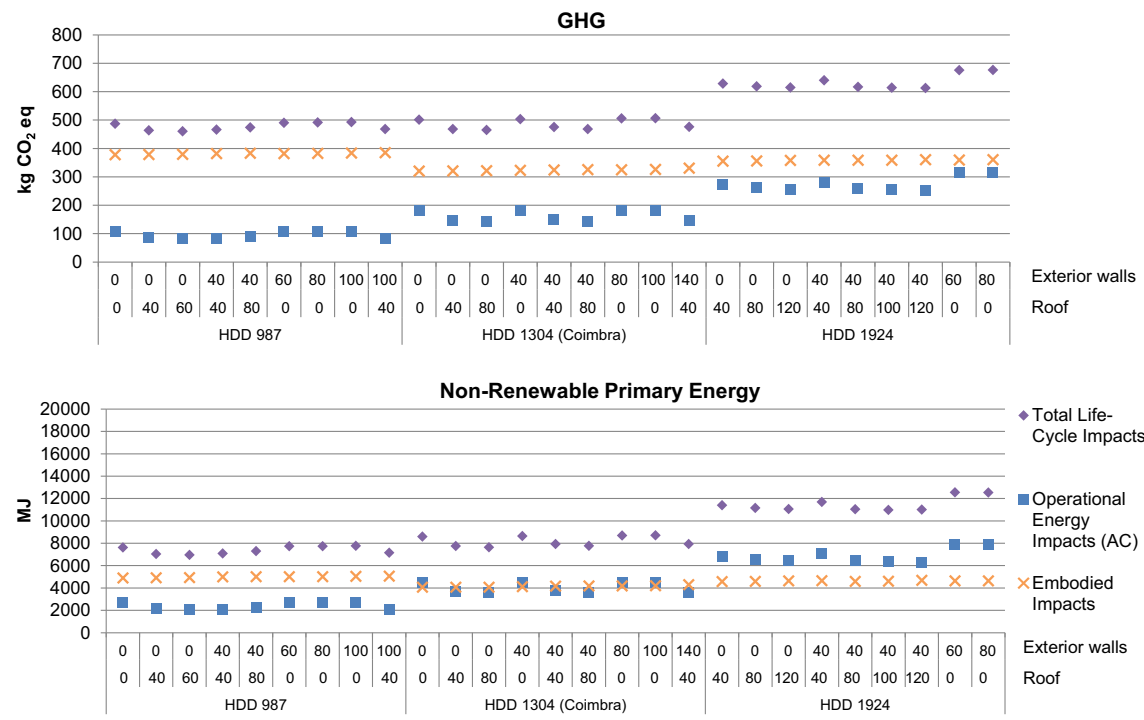

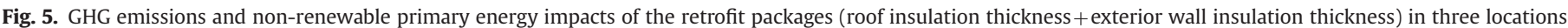
(HDD 987, 1304, and 1924), per functional unit (one square metre of living area over a period of 30 years). 
(varying between categories) while operational energy accounts for 40-65\%. Moreover, GHG and NRPE operational energy impacts offset the embodied impacts in all retrofit strategies. The environmental benefits (reduction in total LC impacts) are very low (reduction of about 3\%) for thicknesses of more than $80 \mathrm{~mm}$ in exterior walls and $120 \mathrm{~mm}$ in the roof.

A sensitivity analysis performed for different heating systems shows that even though AC had lower final energy needs (25-30\% less) than the gas boiler, the latter leads to lower GHG emissions (about 60\%) than the AC as well as fewer non-renewable primary energy impacts (40\%). These differences are due to the systems' efficiency (see Section 3) as well as electricity and natural gas primary energy conversion factors (see Section 2.3).

\subsection{Sensitivity analysis}

A sensitivity analysis was performed to assess the influence of energy price and discount rates on useful energy needs, for all energy efficiency retrofit packages. This analysis showed which variable was most important to the cost-optimal performance. The retrofit packages should comply with the minimum energy requirements [32] and be more cost-effective than the original scenario (existing building), which means they should have lower primary energy needs and life-cycle costs.

Fig. 6 shows significant differences compared with Fig. 3(a). Primary energy ranges from 27.7 to 306.8 [ $\mathrm{kWh} /\left(\mathrm{m}^{2}\right.$ year $\left.)\right]$, whereas with the reduction factor (0.66) it varies from 22.2 to $213.3\left[\mathrm{kWh} /\left(\mathrm{m}^{2}\right.\right.$ year $\left.)\right]$. This analysis shows how the seasonal steady-state method overestimates the energy needs in its calculation by not assuming that households are not usually permanently occupied, as this method does. For example, in the reference building, the average monthly energy bill for heating and DHW alone would be $€ 202.71$ with the reduction factor and $€ 290.84$, considering $100 \%$ of the estimated energy needs by the seasonal method, for Coimbra.

Comparing Fig. 7 with Fig. 3(a) shows that the significant difference in scenarios of energy prices trends (linear increase of $2.5 \%$ versus Eurostat) does not provide significant changes in the costoptimal range for Coimbra. Increasing just the insulation cost is not enough to significantly alter the cost-optimal packages. However, in the financial perspective the global cost ranges from 221.6 to $480\left[€ / \mathrm{m}^{2}\right]$.

Fig. 8 shows the results for the cost-optimal retrofit packages using $\mathrm{FIN}=12 \%$ and $\mathrm{MAC}=6 \%$ as discount rates. Low energy prices combined with high discount rate estimates (as shown in Fig. 8

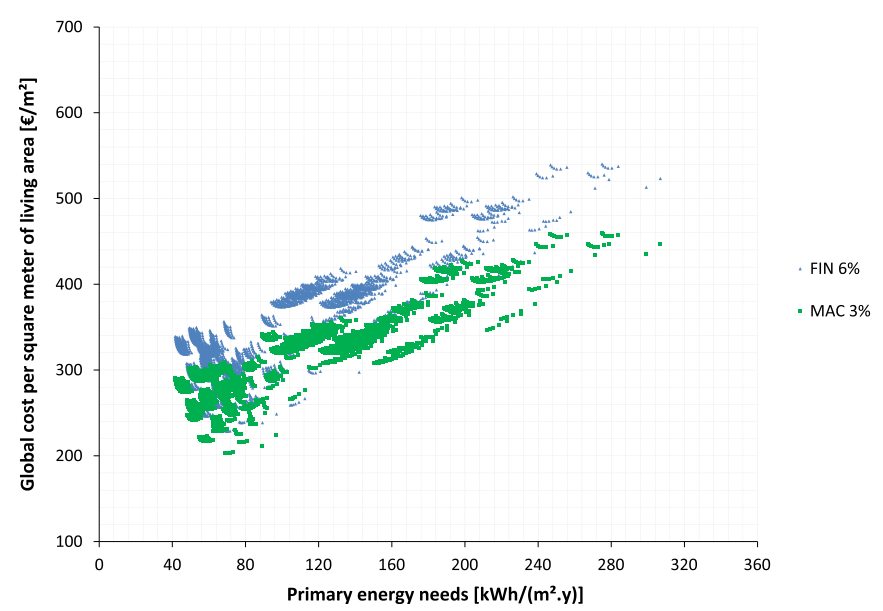

Fig. 6. Global cost $\left[€ / \mathrm{m}^{2}\right]$ and primary energy $\left[\mathrm{kWh} /\left(\mathrm{m}^{2}\right.\right.$ year $\left.)\right]$ results for 4116 retrofit packages, HDD 1304 (Coimbra), considering 100\% of energy needs and estimated by seasonal method, over a period of 30 years.

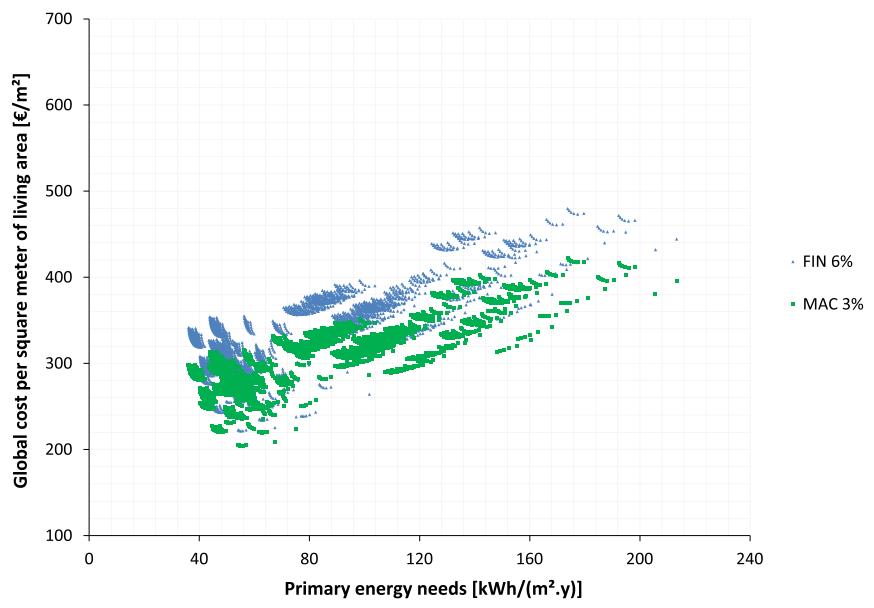

Fig. 7. Global cost $\left[€ / \mathrm{m}^{2}\right]$ and primary energy $\left[\mathrm{kWh} /\left(\mathrm{m}^{2}\right.\right.$ year $\left.)\right]$ results for 4116 energy efficiency retrofit packages, HDD 1304 (Coimbra), assuming a linear trend of $2.5 \%$ for the energy price, over a period of 30 years.
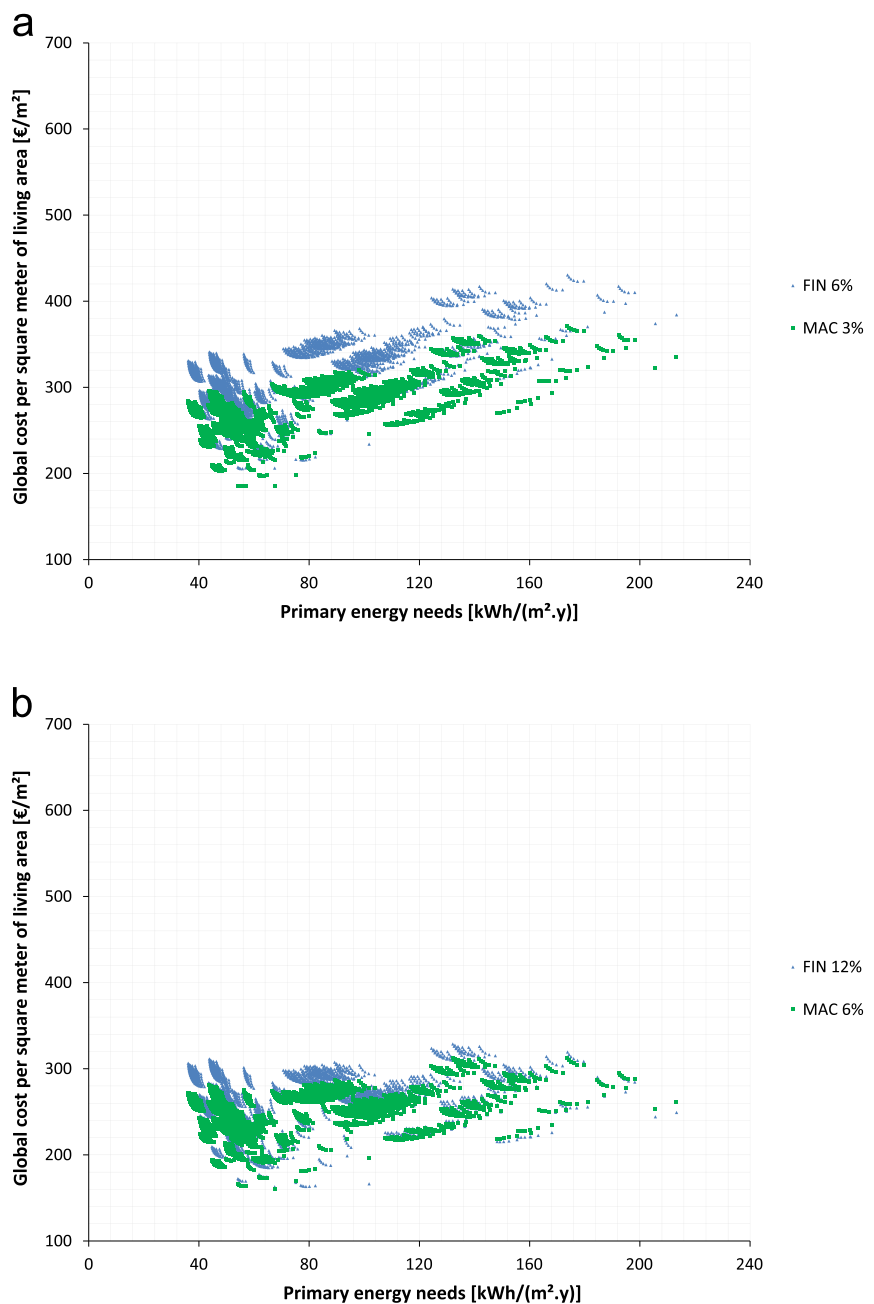

Fig. 8. Global cost $\left[€ / \mathrm{m}^{2}\right]$ and primary energy $\left[\mathrm{kWh} /\left(\mathrm{m}^{2}\right.\right.$ year $\left.)\right]$ results of 4116 energy retrofit packages for HDD 1304 (Coimbra) considering (a) 6\% and (b) 12\% as discount rates; per square meter of living area over a period of 30 years.

(b) discouraged investment in packages with lower primary energy needs. For example, in the financial perspective the global cost ranges from 205.7 to $480.5\left[€ / \mathrm{m}^{2}\right.$ ] for FIN 6\% (Fig. 8 (a) whereas with FIN $12 \%$ it varies from 162.9 to $347.2\left[€ / \mathrm{m}^{2}\right]$ (Fig. 8(b). Note that potential savings on energy costs decrease 
more sharply in packages with higher primary energy needs when the discount rate rises to FIN 12\%. In the scenario with the highest primary energy needs (a building without any efficiency measure, $213.3\left[\mathrm{kWh} /\left(\mathrm{m}^{2}\right.\right.$ year $\left.)\right]$ ), the global cost decreases from 384.2 (FIN $6 \%$ ) to $249.3\left[€ / \mathrm{m}^{2}\right]$ (FIN $12 \%$ ). There is a correlation between the discount rate and the energy price trend, which is relevant for the viability of investment in energy efficiency measures. A higher energy cost encourages increasing investments in retrofit because of the significant potential of energy savings.

\section{Conclusions}

This paper implements an integrated cost optimality and environmental assessment by combining alternative energy retrofit packages for a historic building located in the centre of Coimbra, Portugal (recently classified as a UNESCO World Heritage site). This building is representative of the Portuguese building stock in old city centres dating from the beginning of the 20th century. A number of energy efficiency retrofit packages (combining different energy efficiency retrofit measures) were selected from a preliminary economic assessment. GHG and non-renewable primary energy impacts were assessed. A parametric assessment was performed that combined roof insulation, exterior wall insulation, window replacement, heating and domestic hot water systems, in different locations. The variables assessed were the thermal resistance of the building envelope components (insulation thicknesses), heating and DHW system efficiency, location (heating degree days - HDD) and cost. The operational energy was calculated using both seasonal steady-state and thermal dynamic simulation methods. An occupancy pattern to be representative of the average Portuguese residential buildings was defined in the thermal dynamic model.

The cost optimality assessment was performed in accordance with the European Commission for the calculation of cost-optimal solutions compared with the building energy performance requirements in Portugal [8]. This method reduces the global cost and primary energy needs, which leads to better return on investment and lower environmental impacts. Finally, a sensitivity analysis was performed to assess the useful energy needs variability, energy price and discount rate.

The thickness of the nine retrofit packages selected for each location from the cost-optimal range varied from zero to $140 \mathrm{~mm}$ (when considering the lower bound of prices used in the Portuguese market). However, where the climate is warmer there is no advantage in using thicknesses of more than $80 \mathrm{~mm}$. Price variation (from lower bound to upper bound) influences the cost optimality of the retrofit packages and this requires constant reassessment to achieve expected return on investment.

The economic assessment results showed that, first, there is a correlation between the discount rate and the energy price trend which is important for the viability of investments in energy efficiency measures; but just increasing the energy cost is not enough to significantly alter the cost-optimal packages. Second, lower energy prices combined with higher discount rate estimates discouraged investment in packages with lower primary energy needs. Third, insulation cost $[€ / R]$, heating and DHW systems operating cost $[€ / \mathrm{kWh}]$ and its corresponding efficiency directly influence retrofit package performance. Finally, the energy costs, significantly higher in the financial perspective due to taxes, can encourage investment in retrofit in a private perspective, to take advantage of energy savings.

Extra insulation levels in temperate climates (buildings with lower energy needs) may lead to higher embodied impacts without significantly reducing the operational energy, resulting in higher total life-cycle impacts. Thus, a tipping point occurs when total life-cycle impacts are minimised (presenting an insulation level threshold).

Environmental life-cycle results show that each HDD location had a different insulation level threshold that minimised total LC impacts. The exterior walls' optimum insulation level (LC tipping point) ranged from 40 (HDD 987) to $120 \mathrm{~mm}$ (HDD 1924) and the roof's optimum insulation level ranged from 40 (HDD 987) to $80 \mathrm{~mm}$ (HDD 1304 and 1924). These ranges of insulation thresholds are also within the cost-optimal interval. Additionally, embodied impacts account for 35\% (HDD 1924) to 70\% (HDD 987) while operational energy impacts account for 30\% (HDD 987) to 65\% (HDD 1924). Locations with higher energy needs had higher insulation level thresholds. Lower operational energy needs led to higher embodied impacts. Low energy buildings offer more opportunities to reduce their environmental embodied burden.

Our work demonstrated that extra insulation, i.e. thicknesses of more than $80 \mathrm{~mm}$, does not provide a significantly lower environmental impact or overall cost reduction. Furthermore, even though historic buildings in Portugal do not have to comply with building energy codes, significant energy savings can be achieved without adversely affecting their historic character. It was also concluded that both economic and environmental costs can be minimised by choosing the most suitable energy efficiency retrofit measures.

\section{Acknowledgements}

The first author (S. Tadeu) is grateful for the financial support provided by the Ciência sem Fronteiras Program (Brazil) and acknowledges the support of CNPq (Conselho Nacional de Desenvolvimento Científico e Tecnológico) in Brazil through doctoral degree Grant 237489/2012-0. C. Rodrigues would like to thank FCT (Fundação para a Ciência e a Tecnologia) for financial support under the program MIT Portugal - Sustainable Energy Systems, through the doctoral degree Grant SFRH/BD/51951/2012. The authors are also grateful for the support of Instituto de Investigação e Desenvolvimento Tecnológico em Ciências da Construção (ITeCons), ADENE and the municipality of Coimbra for data used in this research. This work is also related to the Energy for Sustainability Initiative of the University of Coimbra and is supported by the Energy and Mobility for Sustainable Regions-EMSURE-Project (CENTRO-07-0224-FEDER-002004).

\section{References}

[1] I.N.E., DGEG, Inquérito ao Consumo de Energia no Sector Doméstico 2010 2011.

[2] K. Adalberth, Energy use during the life cycle of single-unit dwellings: examples, Build. Environ. 32 (4) (1997) 321-329.

[3] I. Sartori, A.G. Hestnes, Energy use in the life cycle of conventional and lowenergy buildings: a review article, Energy Build. 39 (3) (2007) 249-257.

[4] C. Thormark, A low energy building in a life cycle-its embodied energy, energy need for operation and recycling potential, Build. Environ. 37 (4) (2002) 429-435.

[5] M. Cellura, F. Guarino, S. Longo, M. Mistretta, Energy life-cycle approach in Net zero energy buildings balance: Operation and embodied energy of an Italian case study, Energy Build. 72 (2014) 371-381.

[6] EPDB (recast), Directive 2010/31/EU of the European Parliament and of the Council of 19 May 2010 on the energy performance of buildings (recast), Off. J. Eur. Union L153 (2010) 13-15.

[7] United Nations Environment Program (UNEP), Buildings and Climate Change: Status, Challenges and Opportunities, UNEP, 2007.

[8] E.U., Delegated Regulation (EU), No. 244/2012 of 16 January 2012 Supplementing Directive 2010/31/EU of the European Parliament and of the Council on the Energy Performance of Buildings by Establishing a Comparative Methodology Framework for Calculating Cost-optim, 2012, pp. 18-36.

[9] E.U., Orientações que acompanham o Regulamento Delegado (UE) no. 244/ 2012 da Comissão, de 16 de janeiro de 2012, que complementa a Diretiva 2010/31/UE do Parlamento Europeu e do Conselho relativa ao desempenho 
energético dos edifícios estabelecendo o quadro pa, J. Of. da União Eur. C115 (2012) 1-38.

[10] ISO (International Organization for Standardization), ISO 14040: Environmental Management Life Cycle Assessment Principles and Framework, Geneva, Switzerland, 2006.

[11] A. Dodoo, L. Gustavsson, R. Sathre, Life cycle primary energy implication of retrofitting a wood-framed apartment building to passive house standard, Resour. Conserv. Recycl. 54 (12) (2010) 1152-1160.

[12] L. Liu, B. Moshfegh, J. Akander, M. Cehlin, Comprehensive investigation on energy retrofits in eleven multi-family buildings in Sweden, Energy Build. 84 (2014) 704-715.

[13] B. Nicolae, B. George-Vlad, Life cycle analysis in refurbishment of the buildings as intervention practices in energy saving. Energy Build. 86 (2015) 74-85.

[14] M. Beccali, M. Cellura, M. Fontana, S. Longo, M. Mistretta, Energy retrofit of a single-family house: Life cycle net energy saving and environmental benefits, Renew. Sustain. Energy Rev. 27 (2013) 283-293.

[15] F. Ardente, M. Beccali, M. Cellura, M. Mistretta, Energy and environmenta benefits in public buildings as a result of retrofit actions, Renew. Sustain. Energy Rev. 15 (1) (2011) 460-470.

[16] C. Rodrigues, F. Freire, Integrated life-cycle assessment and thermal dynamic simulation of alternative scenarios for the roof retrofit of a house, Build. Environ. 81 (2014) 204-215.

[17] M. Cellura, F. Guarino, S. Longo, M. Mistretta, Different energy balances for the redesign of nearly net zero energy buildings: an Italian case study, Renew. Sustain. Energy Rev. 45 (2015) 100-112.

[18] M. Cellura, A. Di Gangi, S. Longo, A. Orioli, An Italian input-output model for the assessment of energy and environmental benefits arising from retrofit actions of buildings, Energy Build. 62 (2013) 97-106.

[19] M. Cellura, F. Guarino, S. Longo, M. Mistretta, A. Orioli, The role of the building sector for reducing energy consumption and greenhouse gases: an Italian case study, Renew. Energy 60 (2013) 586-597.

[20] G.A. Norris, B.H. Road, N. Berwick, Integrating life cycle cost analysis and LCA InLCA : selected papers, Int. J. Life Cycle Assess. 6 (2) (2001) 118-120.

[21] L. Gu, B. Lin, Y. Zhu, D. Gu, M. Huang, J. Gai, Integrated assessment method for building life cycle environmental and economic performance, Build. Simul. 1 (2) (2008) 169-177.

[22] M. Ristimäki, A. Säynäjoki, J. Heinonen, S. Junnila, Combining life cycle costing and life cycle assessment for an analysis of a new residential district energy system design, Energy 63 (2013) 168-179.

[23] Lollini Barozzi, Fasano Meroni, Zinzi, Optimisation of opaque components of the building envelope. Energy, economic and environmental issues, Build Environ. 41 (8) (2006) 1001-1013.

[24] D. Anastaselos, E. Giama, A.M. Papadopoulos, An assessment tool for the energy, economic and environmental evaluation of thermal insulation solutions, Energy Build. 41 (11) (2009) 1165-1171.

[25] S. Kim, S. Lee, Y.-J. Na, J.T. Kim, Conceptual model for LCC-based LCCO2 analysis of apartment buildings, Energy Build. 64 (2013) (2013) 285-291.

[26] J. Kneifel, Life-cycle carbon and cost analysis of energy efficiency measures in new commercial buildings, Energy Build. 42 (3) (2010) 333-340.

[27] J.D. Silvestre, J. de Brito, M.D. Pinheiro, From the new European Standards to an environmental, energy and economic assessment of building assemblies from cradle-to-cradle (3E-C2C), Energy Build. 64 (2013) 199-208.

[28] P. Hernandez, P. Kenny, Integrating occupant preference and life cycle energy evaluation: a simplified method, Build. Res. Inf. 38 (6) (2010) 625-637.

[29] A.S. Nordby, Carbon reductions and building regulations : the case of Norwegian mountain cabins, Build. Res. Inf. (2011) 37-41 (no. December 2012).

[30] T. de Meester, A.-F. Marique, A. De Herde, S. Reiter, Impacts of occupant behaviours on residential heating consumption for detached houses in a temperate climate in the northern part of Europe, Energy Build. 57 (2013) 313-323.

[31] E. Azar, C.C. Menassa, A comprehensive analysis of the impact of occupancy parameters in energy simulation of office buildings, Energy Build. 55 (2012) 841-853.

[32] R.E.H., RECS, DL 118/2013-Regulamento de Desempenho Energético dos Edifícios de Habitação, Comércio e Serviços, Code of the energy performance of buildings (residential and commercial), Minist. Econ. Employ. (2013) 4988-5005.

[33] European Committee for Standardization, ISO 13789-Thermal Performance of Buildings-Transmission and Ventilation Heat Transfer Coefficients-calculation Method, 2007.

[34] European Committee for Standardization, ISO 13790-Energy Performance of Buildings-Calculation of Energy Use for Space Heating and Cooling, 2008.

[35] U.S. Department of Energy, EnergyPlus v.8.1 [Online]. Available: 〈http://apps1. eere.energy.gov/buildings/energyplus/〉, 2014.

[36] S.A. CYPE, Ingenieros Gerador de preços para construção civil, 2013.

[37] IPCC, Climate change 2007: the physical science basis, Contribution of Working Group I to the Fourth Assessment Report of the Intergovernmental Panel on Climate Change, Cambridge University Press, United Kingdom and New York, NY, USA, 2007.

[38] S. Tadeu, N. Simões, M. Gonçalves, J. Ribeiro, Energy efficiency measures in portuguese residential buildings constructed before 1960: a cost-optimal assessment, Energy for Sustainability 2013-Sustainable Cities: Designing for People and the Planet, 2013.

[39] F. Nemry, A. Uihlein, C.M. Colodel, B. Wittstock, A. Braune, C. Wetzel, I. Hasan, S. Niemeier, Y. Frech, J. Kreißig, N. Gallon, Environmental improvement potentials of residential, Buildings (IMPRO-Building) (2008).

[40] O. Ortiz-Rodríguez, F. Castells, G. Sonnemann, Life cycle assessment of two dwellings: one in Spain, a developed country, and one in Colombia, a country under development, Sci. Total Environ. 408 (12) (2010) 2435-2443.

[41] D. Kellenberger, H. Althaus, T. Künniger, M. Lehmann, N. Jungbluth, Life Cycle Inventories of Building Products, Ecoinvent Report no. 7, no. 7, 2007.

[42] M. Spielmann, C. Bauer, R. Dones, M. Tuchschmin, Life Cycle Inventories of Transport Services Ecoinvent Report no. 14, vol. 2.0, 2007, pp. 14.

[43] H.-J. Althaus, C. Bauer, G. Doka, R. Frischknecht, N. Jungbluth, T. Nemecek, A Simons, M. Stucki, J. Sutter M., Tuchschmin Documentation of Changes Implemented in Ecoinvent Data v2.1 and v2.2, Ecoinvent Report no. 16, no. July, 2010.

[44] R. Hischier, B.W. Editors, H. Althaus, C. Bauer, G. Doka, R. Dones, R. Frischknecht, S. Hellweg, S. Humbert, N. Jungbluth, T. Köllner, Y. Loerincik, M. Margni, T. Nemecek, Implementation of Life Cycle Impact Assessment Methods, Ecoinvent Report no. 3, vol. 2.2, 2010, pp. 3.

[45] PRé Consultants, SimaPro 8, 〈http://www.pre-sustainability.com/simapro8〉, 2014.

[46] M.C. Peel, B.L. Finlayson, T.A. Mcmahon, Updated World Map of the KöppenGeiger Climate Classification, 2007, pp. 1633-1644.

[47] Comissão Europeia, EU Energy, Transport and GHG Emissions: Trends to 2050, Reference Scenario 2013, 2013.

[48] Entidade Reguladora dos Serviços Energéticos-'Portal ERSE [Online]. Available: 〈http://www.erse.pt/pt/Paginas/home.aspx〉, 2009.

[49] Buildings Performance Institute Europe, Implementing the Cost-optimal Methodology in EU Countries, 2013.

[50] Caixa Geral de Depósitos, Crédito para Reabilitação Urbana, Available: 〈https:/ www.cgd.pt/Particulares/Casa/Credito-Habitacao/Pages/Credito-Habitacao-Re abilitacao-Urbana-Obras.aspx $\rangle$. 